Nippon Suisan Gakkaishi $\quad$ 55(7), 1145-1148 (1989)

\title{
ムラサキイガイの中腸腺内に括ける盲囊細管の分布と 消化過程の同調性
}

\author{
澄 川精 吾, 池田範子 \\ (1988 年 12 月 19 日受付)
}

\begin{abstract}
Synchrony and Distribution of the Digestive Tubules within the Midgut Gland of Mytilus edulis
\end{abstract}

Seigo Sumikawa* and Noriko Ikeda*

\begin{abstract}
A detailed study was made on the distribution of digestive tubules within the midgut gland, to estimate digestive phase in each specimen of the mussel Mytilus edulis.

Of the three parts (anterior, middle and posterior) in cross sections of the midgut gland, the middle contained more numerous tubules (about 1200 tubules) than the other two (about 1000 , respectively). In each section, the tubules within the right half were approximately equal in number to those in the left half and the abdominal area contained more tubules than the dorsal. The mussels examined did not show two types of synchrony (monophasic and diphasic), and all four tubule types were always observable throughout the diverticula in each specimen collected.

Therefore, it is concluded that the samples obtained from an overall area of a right or left half in the cross section of the midgut gland are adequate than those from the dorsal or abdominal area for estimation of the digestive phase in the mussel specimen.

The clustering of the tubules around common and neighboring secondary ducts showed similar tubule types in the histological structure.
\end{abstract}

二枚貝の消化は胃に打ける細胞外消化と中腸腺盲塞細 管での細胞内消化が観察されているが，とくに多くの種 において，盲要細管とをれを構成する消化細胞の形態が 消化過程の進行につれて変化することが報告されてい る。

消化細胞内の消化過程はおよそ4相に区分され，従。 てこの細胞より構成されている盲董細管す 4 型すなわち Type I (holding or normal), Type II (absorptive and digestive), Type III (disintegrating), と Type IV (reconstituting)に分けられ。 ${ }^{10,13,14)}$ 潮汐のリズムあるいは 摄餌のリズムと関連して, 中腸腺内の盲軎細管が同調变 化し，全盲鸾細管が同じ相を示す峃一相型 monophasic, ${ }^{4-8,12,13)}$ と全体の盲襄細管のらち半数ずつの盲 婁細管が同調し，4 相の消化過程が半周期ずれて变化す る二相型 diphasic ${ }^{1,2,11,12)}$ とが報告されている。

最近, 数種の二枚貝において, 1 個体内での中踢腺の

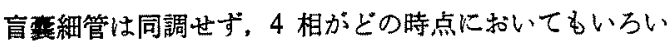
ろの割合に現われるので, ${ }^{10,14-18)}$ その個体の中腸腺の相 表現は優勢な盲震細管の相で示すべきであるといら報告
がある。

消化細胞の同調性について，その結果がこのように不 一致であるのは，個体の中腸腺がどの相にあるかを判定 するために用いだ腸腺内の測定部位掞よび盲塞細管数 が研究者によってまちまちであったことが原因の一っで あると考觉られる。

それ故本研究は中潮帯に生息し，二枚貝の掑慨と消化 および貝類による水質污染の評価の材料として最もよく 用いられるムラサキイガイについて，盲塞細管の中晹腺 内に淤䂗数と分布を明らかにし, 上り適正な測定部位 の選択と方法によって消化過程の同調性を検討すること を目的とした。

\section{材料および方法}

ムラサキイガイ Mytilus edulis は博多染に面した福岡 市東区西戸崎の栈橋で，1983 年 7 月に採集した。殼長 6 7 cm の成体 36 個を採集し, 值ちに中腸腺を取り出 してブアン液で固定し，常法によってバラフィンに包埋 し， $9 \mu \mathrm{m}$ の助片を作製した。へマトキシリン・エオン

* 福岡女子大学家政学部 (Faculty of Home Life Science, Fukuoka Women's University, Fukuoka 813, Japan). 
ンの二重染色を施して顕豃鏡観察をおこなった。

盲㖟細管の消化過程の相判定は Langton ${ }^{10)}$ に従って, Type 1, II, III, IV 4 段倩とした。

\section{結果および考察}

目金絧管の分布 中晹腺全体を前部，中部，後部の3 部に区分し，その各部から紗片を選び出した（Fig. 1)。 各部における盲要細管の分布状態を模式的に示したのが Fig. 2 である。図に示したように中部は他の2 部に比べ

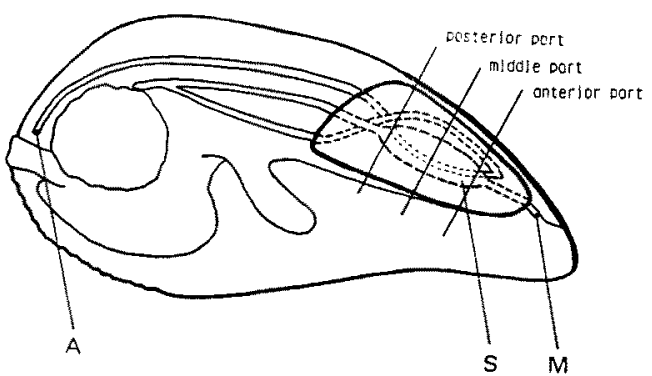

Fig. 1. Position of transversal section in the midgut gland of Mytilus edulis.

A: anus, $\mathrm{M}$ : mouth, $\mathrm{S}$ : stomach.
て、盲盖細管の分布が全体にわたって密であり，前部と 後部は左右の側縁に少しかたよって多く分布し，胃の周 りには比較的に少なかった。3 部とる腹側には音童細管 全数の半分以上が分布しているが, 結合組織の占める割

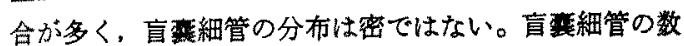
量を 36 個体たついてまとめたるのが Fig. 3 である。こ れから明らかなよ5に中部に富菻細管は最す多く分布 し，切片あたり約 1,200 個、前部之後部は经活同数て約 1000 個が観察され中部より少なかった (Fig. 3, 左)。背 部と腹部では腹部に多く(Fig. 3,中), 左右はほとんど同 数す゚つ分布していた。このことは胃からの主尊管 main duct が左右住ば 同数分技しているすのと考之られる。 てれ故 1 個体の消化過程の相を決定するためには，中叞 怔の前, 中，後部上も切片断面のうち，左右のいずれか 半分の部分を全体にわたって測定する必要があると考え られる。

消化過程の同調性 淦潮時に海水に浸っている個体と 干潮時に露出している個体のいずれの中得腺に㖉いてす Type I から Type IVまでの 4 相が観察された。その代 溇的なるのを Fig. 4 に示す。

一つの切片の断面で観察された同じ相の盲哀細管は部
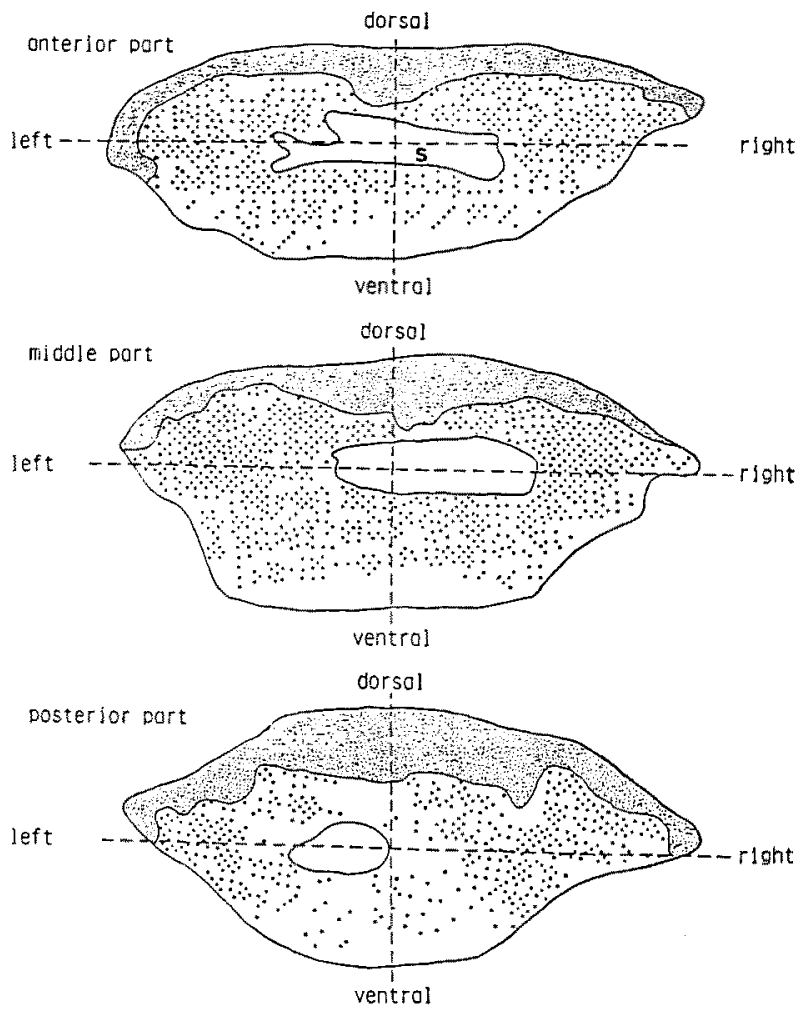

Fig. 2. Distribution of the digestive tubules of the cross sections in different parts of the midgut gland. Dorsal dotted area: a part of the gonad, S: stomach. 

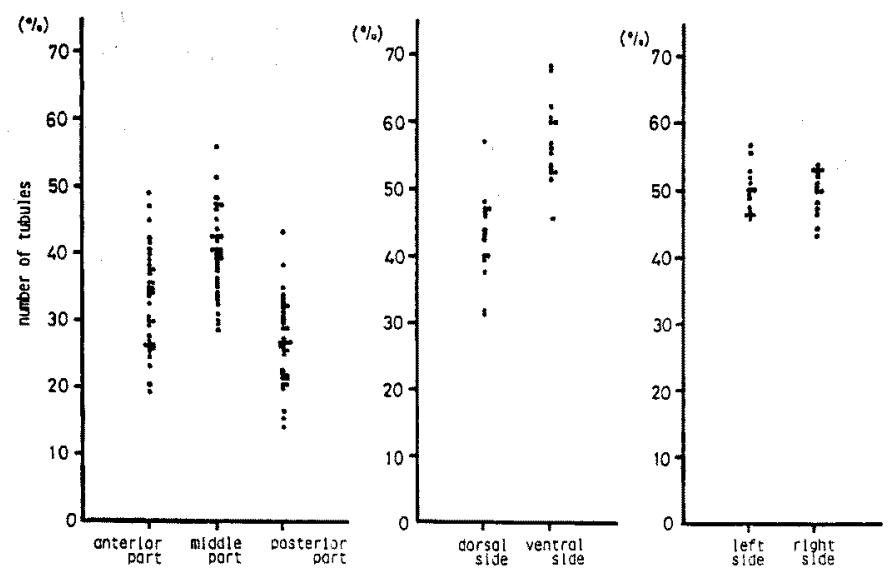

Fig. 3. Distribution of the digestive tubules in different parts and sides of the cross section.

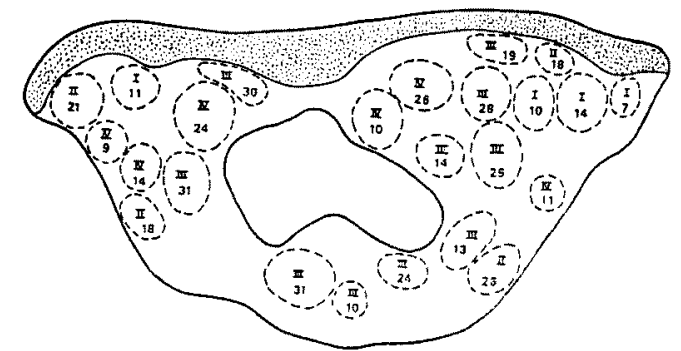

Fig. 4. Distribution of sychronized tubules. Areas surrounded by the broken line show ranges of synchronized tubules in middle part.

Roman numerals: tubule types, Arabic numerals: the number of tubules.

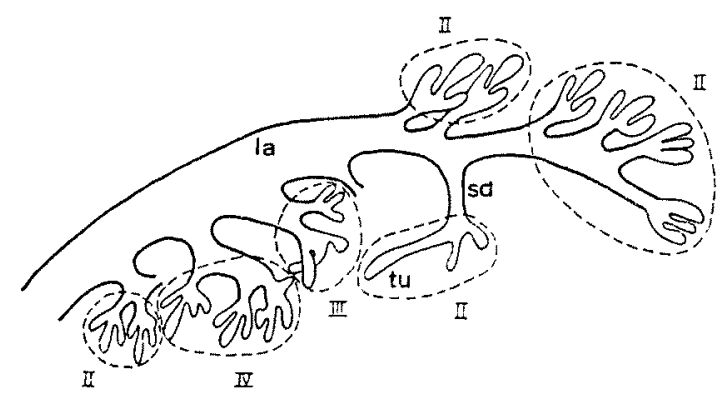

Fig. 5. Secondary ducts with tufty tubules and lateral ducts in some lobules of the midgut gland.

Roman numerals: tubule types, sd: secondary duct, la: lateral duct, tu: tubule.

分的に限られており，同し相の7 個以上の盲霜細管が集 って同調している部分を破線で囲んで示している。この 他 2〜6 個の盲重細管が同調しているのが钼察された。 ムラサキイガイについては Langton ${ }^{10)}$ が同様に 4 相の 同時出現を観察し；とくに Type I と II が多いことを
報告している。彼は同調性が見られない原因を推諭し， 同一中腸腺内の各盲程細管への䬣料の到達が同時でない ことをあげている。同様な現象が Ostrea edulis ${ }^{10,15\rangle}$ と Mercenaria mercenaria ${ }^{14,10)}$ でも報告されており, 同調 するのは共通の介在小管 secondary duct をもつ盲栾細 
管の房だけであると結論している。

それ故今回の観察に括いてて数枚の連繶切片から一房 の中腸腺小葉の立体構造を組み立てて，盲毫細管とその 相の状態を険討した (Fig. 5)。これによると同じ介在小 管から出ている盲变細管は全て同じ相を示し，近接して いる介在小管から出ている盲露細管も消化過程の同調を 示した。多い例として約 30 個の盲栾細管が-つの集り となって同調を示していた。

以上のことから、ムラサキイガイにおいては同一個体 内の中腸腺の盲恋細管が広範围に同調することはなく， 消化過程の 4 相は常に共存するものと判断された。

\section{文献}

1) J. E. Morton: J. Mar. Biol. Ass. U.K., 35, 563-586 (1956).

2) R. W. McQuiston: Prac. Malac. Soc. Lond., 38, 483-491 (1969).

3) B. S. Morton: Proc. Malac. Soc. Lond.; 38, 401-414 (1969).

4) B.S. Morton: J. Mar, Biol. Ass. U.K., 50, 499-512 (1970).
5) B. S. Morton: Malac. Rev., 3, 115-119 (1970).

6) B. S. Morton: Biol. J. Linn. Soc., 3, 329-342 (1971).

7) B. S. Morton: J. Zool. Lond., 179, 437-466 (1976).

8) B. S. Morton: J. Exp. Mar. Biol. Ecol., 26, 135-151 (1977).

9) G. Owen: Sci. Prog. Oxford, 60, 299-318 (1972).

10) R. W. Langton: J. Mar. Biol. Ass. U.K., 55, 221-229 (1975).

11) N. F. Mathers: J. Exp. Mar. Biol. Ecol., 24, 271-283 (1976).

12) N. F. Mathers, T. Smith, and N. Colins: $J$. Moll. Stud., 45, 68-81 (1979).

13) P. S. Hameed and A. L. Paulpandian: Indian J. Mar. Sci., 16, 151-154 (1987).

14) W. E. Robinson and R. W. Langton: Mar. Biol., 58, 173-179 (1980).

15) W. E. Robinson, M. R. Pennington, and R. W. Langton: J. Exp. Mar. Biol. Ecol., 54, 265-276 (1981).

16) J. H. Wilson and R. W. LaTouche: Mar. Biol., 47, 71-77 (1978). 